\title{
Individual Student Planning Services with Web 2.0
}

\author{
Gantina Komalasari $^{1^{*}}$, Wening Cahyawulan ${ }^{2}$, Aip Badrujaman ${ }^{3}$ \\ ${ }^{1}$ Department of Psychology, Universitas Negeri Jakarta, Jakarta, Indonesia \\ ${ }^{2,3}$ Department of Guidance and Counseling, Universitas Negeri Jakarta, Jakarta, Indonesia
}

\begin{abstract}
Individual student planning as one of the components in the guidance and counseling comprehensive program provides services to help students understand and monitor their growth and development in order to take action on their next steps. School counselors need to adapt to today's era in order to help students who are the part of the digital age. Web 2.0 is a recommendation for future career intervention. Web 2.0 tools and resources encourage collaboration between students and a careers counselor. The research method that was used was design-based research (DBR) and the model that is implemented is the Integrative Learning Design (ILD). The web 2.0 content is divided into two descriptions which are individual student planning strategies (individual appraisal, individual advisement, transition planning, and follow up) and peminatan (specialization) which describes the high school curriculum. This paper will discuss how web 2.0 tools can be developed and implemented in guidance and counseling services, specifically the individual student planning component.
\end{abstract}

Keywords

Individual student planning; Web 2.0; Design-based research

Article Received: 20 September 2020, Revised: 30 November 2020, Accepted: 18 December 2020

\section{Introduction}

Careers are an important aspect of developing a life path that brings satisfaction and cohesion. In an educational setting, it was found that counseling was often sought out to address career issues. Florian (Florian, 1983) stated that the highest need for counseling services in high school was with regards to finding a career path. Lehmanowsky (Lehmanowsky, 1992) explained that career planning issues was the highest priority counselor services that were needed by students in high school. Morganfield's (2012) findings showed that students in high school needed counseling activities which focus on higher education and career readiness.

Guidance and counseling regulations in Indonesia have created a program that provides four services, adapted from guidance and counseling comprehensive program (Gysbers, 2008). They are guidance curriculum, responsive, individual student planning, and system support (Gysbers, 2013). Students' needs about services that focus on career planning are described in the individual student planning. Gysbers (Gysbers, 2008) Individual student planning has the biggest portion in the guidance and counseling program, so there is no doubt that school counselors need to focus on providing this service to the best of their abilities.

Jencius and Rainey (Jencius \& Rainey, 2009) described that in the future, career services should use web 2.0 platforms such as that which Purdue University Career Wiki have already created (that can be accessed through http://career.lib.purdue.edu/). Web 2.0 is believed to provide the public with more opportunities to work, connect, and provide services together, because web 2.0 has three key characteristics, which are: open, social, and user-oriented (Van Berlo, 2011).

This research will develop individual student planning services through a web 2.0 platform for students in one of the international high schools in Jakarta. High school students are adolescent, a stage in developmental psychology where psychological help is needed the most (Campbell \& Glasheen, 2012). High school students are at the beginning stages of creating a career plan to enhance their lives and fulfil their potential, in which they will need to work towards by completing higher education and/or seeking job opportunities and apprenticeships to build their future. 
As technology continues to progress, the individual student planning service needs to transform and upgrade from conventional methods to online services. Technology implementation in guidance and counseling services, especially in the career domain, have been developed in recent years. Online career counseling had been created by Nota, Santili, and Soresi (Nota, Santilli, \& Soresi, 2016) in Italia. Herman (Herman, 2010) developed Career HOPES which is a career group intervention over four weeks. Glessner, Rockinson-Szapkiw, and Lopez (Glessner, Rockinson-Szapkiw, \& Lopez, 2017) did an experiment with online intervention for students in West-Central Florida.

Development of online guidance and counseling services is an adaptation for today's users. In this era, adolescents use internet technology as a part of their daily social life (Campbell \& Glasheen, 2012). The main uses are synchronous communication, such as chat, and asynchronous communication such as email, facebook, etc.

This research focuses on developing individual student planning services based on web 2.0 platform for high school students, especially an international school in Jakarta.

\section{Individual Student Planning}

The guidance and counseling comprehensive program started when Gysbers and Henderson (1988) developed its stages: planning, designing, implementing, and evaluating. In 2012, the counseling comprehensive program was described as consisting of guidance curriculum, responsive, individual student planning, and support system (Gysbers and Henderson, 2012).

The individual student planning component is one of many elements in the guidance and counseling comprehensive program, provided by a counselor to assists students with developing and using individual learning plans (personal plans of study, career plans, students education, and occupational plans (Gysbers, 2013). Although individual student planning starts from middle school, guidance curriculum is an extremely important component that has to be provided during elementary school as a foundation for individual student planning (Gysbers, 2013). Discussions during elementary school include self-concept development, the acquisition of learning to learn skills, interpersonal relationship skill development, decision-making skill building, awareness and beginning the exploration of educational and occupational possibilities. In comparison, high school counselors spend the highest time portion of the guidance and counseling program to deliver individual student planning services (Johnson, 2018). The services continue to provide new information and experiences to help high school students update and monitor their plans regularly and effectively (Gysbers \& Henderson, 2014).

Based on ASCA counselor competencies, individual student planning is one of the skills that a counselor needs to have (Association, 2012). They enable counselors to provide strategies for appraisal, advisement, goal-setting, decisionmaking, social skills, transition or post-secondary planning.

Implementation strategies of individual student planning are:

- Individual appraisal, which is the services that help students to assess and interpret their characteristics (abilities, interests, skills, and achievement).

- Individual advisement is when School counselors assist students to use self-appraisal information along with personal-social, academic, career, and labor market information to help them plan for and realize their personal, social, academic, and career goals.

- Transition planning: School counselors and other education personnel assist students to make the transition from school to work or to additional education and training.

- Follow-up: School counselors and other education personnel provide follow-up assistance to students as well as gather followup data for evaluation and program.

Gysbers (Gysbers \& Henderson, 2014) described the look of individual student planning in action in two examples, which are Student Education Occupation Plan or SEOP (which already changed its name into College and Career Readiness Plan or CCR Plan) that is developed by Granite School 
District in Utah and Navigation 101 by Franklin Pierce School District in Washington State.

In Indonesia, there is a regulation that describes the guidance and counseling comprehensive program which is employed by the Ministry of Education. The individual student planning services are adapted in Indonesia to encourage the need to provide specialization (peminatan) as a part of the curriculum in high school.

\section{Web 2.0}

After the era of web 1.0 sites which are static, not interactive, and application proprietary, Web 2.0 was developed to make people not only active in receiving or searching for information, but also building and collaborating in a different way, using tools to design and create (Berube, 2011).

There are some career blogs that were developed by using web 2.0 platform, such as Monster blog, Boston Work's, Employment Digest, Career and Job Hunting Blog, and Today's Workplace (Jencius \& Rainey, 2009).

Web 2.0 offers the public more opportunities to productively organize themselves, work together, collect and remix content, because web 2.0 has three characteristics, which are (Van Berlo, 2011): Open, enabling web 2.0 to be accessible and transparent.

Social, allowing communication between people.

User-oriented, provides users with the opportunity to do what they like.

\section{Method}

This study used design-based research (DBR), a method developed for education (Anderson and Shattuck, 2012). Design based research is "an emerging paradigm for the study of learning in context through the systematic design and study of instructional strategies and tools" (Collective, 2003). DBR has five basic characteristics, which are (a) pragmatic, (b) grounded, (c) interactive, iterative, and flexible; (d) integrative; and (e) contextual (Wang \& Hannafin, 2005).

The DBR model that was used is Integrative Learning Design (ILD), a framework that provides a comprehensive and flexible that positions design search as a socially constructed (Bannan, 2009). Bannand (Kelly, Lesh, \& Baek, 2014) claimed that ILD is a guidance of the design research process of designing, developing, and assessing the impact of an educational innovation. ILD phases are (a) Informed Exploration, (b) Enactment, (c) Evaluation: Local Impact, and (d) Evaluation: Broader Impact (Bannan-Ritland \& Baek, 2014).

This study was the result of a collaboration between a researcher and a school counselor in which research has been conducted. Information is collected through interviews and questionnaires.

\section{Discussion}

\section{Informed Exploration Phase}

This is the first stage in which the researcher explores the ideals and perceptions of the target audience. The principal of the high school strongly supports this website development, because as the school counselor describes, career planning is the most demanding service in the school. Discussions with students revealed that they have an interest to plan their major and university in the future. The school counselor stated that: "unlike students in the past who are more interested to continue their education in private universities, students nowadays start to have interest to continue study in public universities."

From the description that researchers received from the school counselor and students, a compilation of suggestions to improve individual student planning activities through web 2.0 has been formulated as shown in table 1 .

Individual student planning strategies that are described by Gysbers and Handerson (Gysbers, 2013) become the core theory of web development. Based on needs description, the web 2.0 will have individual appraisal, individual advisement, transition planning, and follow-up. The researcher also uses all of the information about universities and the education system in Indonesia as part of the web content. 
Table 1. Need analysis

\begin{tabular}{ll}
\hline \multicolumn{1}{c}{ Individual Student Planning Activities } & \multicolumn{1}{c}{ Description } \\
\hline Specialization (peminatan) & $\begin{array}{l}\text { The curriculum that is used in the school is the 2013 } \\
\text { curriculum. }\end{array}$ \\
Individual appraisal & $\begin{array}{l}\text { The school counselor has a collaboration with the } \\
\text { psychologist to do the career assessment. } \\
\text { It is needed to help students understand their } \\
\text { assessment result, but the school counselor does not } \\
\text { have enough time to give information to every student } \\
\text { in the school. }\end{array}$ \\
& $\begin{array}{l}\text { It is provided through discussion between the school } \\
\text { counselor and students. }\end{array}$ \\
Transition planning & There are no follow up activities in school for alumni. \\
\hline
\end{tabular}

The majority of students in the high school are Chinese, of which come from a high social class evidence therefore suggests that they are more inclined to attend private universities that are not only more expensive, but also try to isolate themselves from the local ethnic. In Indonesia, there are only $1,2 \%$ of citizens who are Chinese while most citizens are Javanese (Statistik, 2011).

\section{Enactment Phase}

At this stage, the researcher and school counselor discussed the learning targets for innovation. The goal is so that students can plan their future by choosing the right major and university for them. Students can not only access the web at anytime and anyplace, but also have a consultation with the school counselor through chatting and forum tools.

Table 2. Design research conjectures

\begin{tabular}{ll}
\hline \multicolumn{1}{c}{ Individual Student Planning Activities } & \multicolumn{1}{c}{ Web 2.0 Description } \\
\hline Specialization (peminatan) & $\begin{array}{l}\text { Web will provide the description about the subject of 2013 } \\
\text { curriculum, especially about specialization (peminatan) }\end{array}$ \\
Individual appraisal & $\begin{array}{l}\text { Web will describe that every student will get a career } \\
\text { assessment }\end{array}$ \\
Individual advisement & $\begin{array}{l}\text { Web will give information about the result of the individual } \\
\text { appraisal }\end{array}$ \\
Transition planning & $\begin{array}{l}\text { The web will provide a portfolio to help students consider their } \\
\text { potential and plan their career }\end{array}$ \\
Follow-up & Web will have a form that will be filled by alumni
\end{tabular}

\section{Evaluation: Local Impact}

In this stage, the web is used by the students (voluntarily) and the counselor to collect information about the impact of the web.

The school counselor states that the web is highly demanded because of its popularity. The web help counselor is able to deliver individual student planning services in a smaller amount of time, as opposed to having only one counselor who is responsible for all of the high school students.
Formative evaluation is conducted at this stage, in this case the students' career plan that described on the portfolio.

\section{Evaluation: Broad Impact}

The research results are published to the public at this point, and the development of web 2.0 needs to be diffused, adopted, and adapted. From there, people can see the consequences of the web. 


\section{Conclusions}

Based on the research, web 2.0 is a strong recommendation for guidance and counseling activities, especially with the individual student planning component. The web 2.0 enables students to actively search and receive information, which serves as a benefit due to the relationship between millennials and the internet.

Overall, the consequences of web development need further discussion and research as the web is only implemented in a private high school in Indonesia.

\section{References}

[1] Association, A. S. C. (2012). ASCA school counselor competencies. Alexandria, VA: Author.

[2] Bannan-Ritland, B., \& Baek, J. Y. (2014). Investigating the act of design in design research: The road taken Handbook of design research methods in education (pp. 317-337): Routledge.

[3] Bannan, B. (2009). The integrative learning design framework: An illustrated example from the domain of instructional technology. An introduction to educational design research, 53-73.

[4] Berube, L. (2011). Do you Web 2.0?: public libraries and social networking: Elsevier.

[5] Campbell, M. A., \& Glasheen, K. (2012). The provision of online counselling for young people Online guidance and counseling: Toward effectively applying technology (pp. 1-13): IGI Global.

[6] Collective, D.-B. R. (2003). Design-based research: An emerging paradigm for educational inquiry. Educational Researcher, 32(1), 5-8.
[7] Florian, K. M. (1983). Student Counseling Needs, Sources, and Counseling Program of Washington High School.

[8] Glessner, K., Rockinson-Szapkiw, A. J., \& Lopez, M. L. (2017). "Yes, I Can": Testing an Intervention to Increase Middle School Students' College and Career Self-Efficacy. The Career Development Quarterly, 65(4), 315-325.

[9] Gysbers, N. C. (2008). Individual student planning in the United States: Rationale, practices, and results. Asian Journal of Counselling, 15(2), 117-139.

[10] Gysbers, N. C. (2013). Career-ready students: A goal of comprehensive school counseling programs. The Career Development Quarterly, 61(3), 283-288.

[11] Gysbers, N. C., \& Henderson, P. (2014). Developing and managing your school guidance and counseling program: John Wiley \& Sons.

[12] Herman, S. (2010). Career HOPES: An Internet-delivered career development intervention. Computers in Human Behavior, 26(3), 339-344.

[13] Jencius, M., \& Rainey, S. (2009). Current online career counseling practices and future trends. Career Planning and Adult Development Journal, 25(3), 17-28.

[14] Johnson, G. S. (2018). Individual Student Planning School Counselors as Practitioners (pp. 83-106): Routledge.

[15] Kelly, A. E., Lesh, R. A., \& Baek, J. Y. (2014). Handbook of design research methods in education: Innovations in science, technology, engineering, and mathematics learning and teaching: Routledge. 
[16] Lehmanowsky, M. B. (1992). Guidance and counseling services: Perceived student needs.

[17] Nota, L., Santilli, S., \& Soresi, S. (2016). A life-design-based online career intervention for early adolescents: Description and initial analysis. The Career Development Quarterly, 64(1), 4-19.

[18] Statistik, B. P. (2011). Kewarganegaraan, suku bangsa, agama, dan bahasa sehari-hari penduduk Indonesia: Hasil sensus penduduk 2010. Jakarta: BPS.

[19] Van Berlo, D. (2011). Civil Servant 2.0: New ideas and practical tips for working in government 2.0: Davied van Berlo.

[20] Wang, F., \& Hannafin, M. J. (2005). Designbased research and technology-enhanced learning environments. Educational technology research and development, 53(4), 5-23. 